\title{
Evaluation of Strontium Isotopes as a Geochemical Tracer in the Middle Fork Mineral Creek Basin, Southwestern Colorado
}

Water-Resources Investigations Report 00-4290

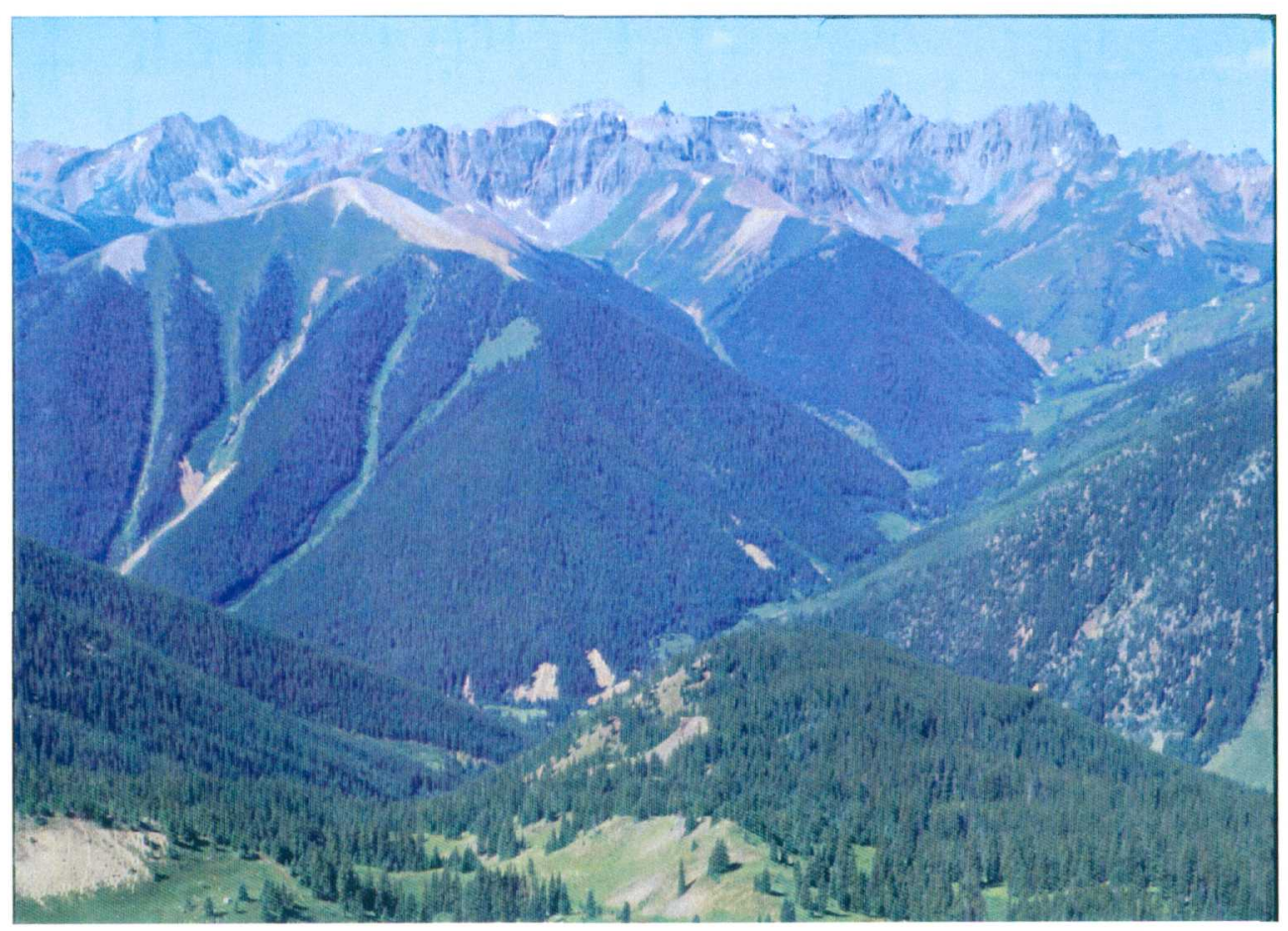

U.S. DEPARTMENT OF THE INTERIOR

U.S. GEOLOGICAL SURVEY 
U.S. DEPARTMENT OF THE INTERIOR

U.S. GEOLOGICAL SURVEY

\section{Evaluation of Strontium Isotopes as a Geochemical Tracer in the Middle Fork Mineral Creek Basin, Southwestern Colorado}

By Philip L. Verplanck, Daniel M. Unruh, and David L. Fey

Water-Resources Investigations Report 00-4290

Denver, Colorado 2001 


\section{U.S. DEPARTMENT OF THE INTERIOR \\ Gale A. Norton, Secretary}

U.S. GEOLOGICAL SURVEY

Charles G. Groat, Director

The use of trade, product, industry, or firm names in this report is for descriptive purposes only and does not imply endorsement by the U.S. Government.

For additional information write to: Copies of this report can be purchased from:

Chief, Branch of Regional Research U.S. Geological Survey

Box 25046, MS 418

Denver Federal Center

U.S. Geological Survey Information Services

Box 25286

Denver Federal Center

Denver, CO 80225

Denver, CO 80225 


\section{CONTENTS}

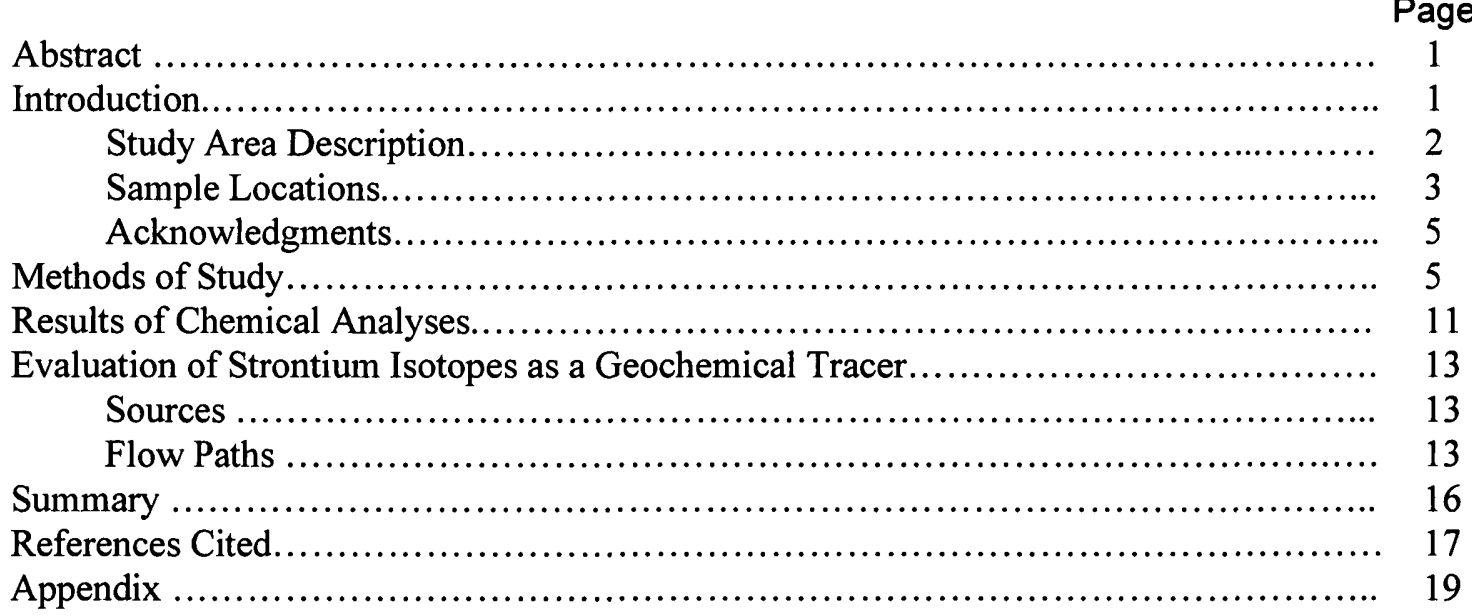

Figures

1. Map showing location of the study area, primary geographic features, generalized alteration assemblages, and sample locations

2-5. Graphs showing ${ }^{87} \mathrm{Sr} /{ }^{86} \mathrm{Sr}$ ratio and:

2. Strontium concentration of water samples......................... 9

3. $\mathrm{pH}$ value of water samples ................................... 9

4. ${ }^{87} \mathrm{Rb} /{ }^{86} \mathrm{Sr}$ ratio of whole-rock samples ............................. 10

5. 1/strontium concentration of 4-hour leachates........................ 10

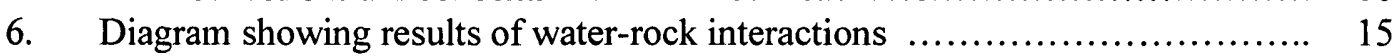

\section{Tables}

1. Selected elemental concentrations of whole-rock samples................... 4

2. Selected characteristics of water samples................................. 6

3. Chemical compositions of leachates..................................... 7

4. Strontium isotopic compositions of whole-rock and leachate samples............ 12 


\title{
Evaluation of Strontium Isotopes as a Geochemical Tracer in the Middle Fork Mineral Creek Basin, Southwestern Colorado
}

\author{
By Philip L. Verplanck, Daniel M. Unruh, and David L. Fey
}

\begin{abstract}
Sources and hydrologic flow paths need to be determined to evaluate remedial options in miningaffected basins. The ${ }^{87} \mathrm{Sr} /{ }^{86} \mathrm{Sr}$ ratios of a suite of water and rock samples from the Middle Fork Mineral Creek basin in the upper Animas River watershed, Colorado, were determined to investigate their possible use as a geochemical tracer for sources and flow paths. Leaching experiments were performed on the dominant lithologies in the study area to determine the more easily weathered constituents, including strontium.

Variations in whole-rock ${ }^{87} \mathrm{Sr} /{ }^{86} \mathrm{Sr}$ ratios correlate with lithology and hydrothermal alteration intensity. For a given alteration assemblage, the porphyritic quartz monzonite has a lower ${ }^{87} \mathrm{Sr} /{ }^{86} \mathrm{Sr}$ ratio than the surrounding San Juan Volcanics, and for a given lithology the ${ }^{87} \mathrm{Sr} /{ }^{86} \mathrm{Sr}$ ratio is lower for propylitically altered rocks than for quartz-sericite-pyrite altered rocks. The ${ }^{87} \mathrm{Sr} /{ }^{86} \mathrm{Sr}$ ratios of waters draining different lithologies and alteration assemblages have correspondingly different strontium isotopic ratios. The age of magmatism and alteration is relatively young (28 -25 million years) compared to the half-life of ${ }^{87} \mathrm{Rb}$, so that the isotopic variation is not great enough to determine mixing ratios for waters derived from multiple sources. In this study area, mine drainage does not have a unique strontium isotopic composition because the mined areas do not have a strontium isotopic composition distinctly different from the unmined, mineralized host rocks.
\end{abstract}

\section{INTRODUCTION}

Strontium isotopic systematics have been used for nearly four decades to constrain theories of planetary evolution (for example Gopalan and Wetherill, 1970; Minster and Allegre; 1976), earth forming processes (Armstrong, 1968), magmatic sources (Hurley and others, 1965), and the timing of metamorphic events (Moorbath and others, 1977). More recently, strontium isotopic compositions have been used to investigate weathering processes and to quantify elemental fluxes at both the watershed and global scales (Aberg and others, 1989; Bain and Bacon, 1994; Clow and others, 1997), as well as to identify ground-water flow paths (McNutt and others, 1990; Bullen and others, 1996).

The concentration of strontium in ground water generally is low, 5 to 20 micrograms per liter $(\mu \mathrm{g} / \mathrm{L})$; therefore, the isotopic composition can be easily affected by interaction with rocks along the flow path (Wadleigh and others, 1985). The strontium isotopic composition of volcanic and plutonic rocks is a function of the initial isotopic composition and the amount of radioactive decay of ${ }^{87} \mathrm{Rb}$ to ${ }^{87} \mathrm{Sr}$, which has a half-life of $48.8 \times 10^{9}$ years. Because individual minerals within a rock can have very different rubidium to strontium ratios, the strontium isotopic ratios of waters interacting with rocks may not reflect the whole-rock strontium isotopic composition but more likely reflect the isotopic composition of the more easily weathered components (Kendall and others, 1995).

Sources and hydrologic flow paths need to be determined to evaluate remedial options in miningaffected basins. Within the U.S. Geological Survey's (USGS) Abandoned Mine Lands Initiative, different geochemical tools have been utilized to evaluate ground-water flow paths and identify sources of metalrich drainage. The strontium isotopic compositions of a suite of water and rock samples from the mining- 
affected Middle Fork Mineral Creek (MFMC) basin, in the upper Animas River watershed, Colorado were determined to evaluate their possible use as a geochemical tracer. This report presents results of the study, including strontium isotopic compositions from a suite of water and rock samples and isotopic and elemental data from leachates of the rock samples.

\section{Study Area Description}

The drainage area of the MFMC lies within the Ophir and Silverton quadrangles in the western San Juan Mountains of southwestern Colorado. The MFMC basin, approximately $25 \mathrm{~km}^{2}$, ranges in elevation from 3,000 meters (m) at the confluence with Mineral Creek to 4,075 $\mathrm{m}$ at Lookout Peak. The bedrock geology was mapped by Luedke (1996), and the alteration assemblages were mapped by Ringrose (1982). The bedrock consists primarily of pyroclastic and lava flows with intermediate to silicic composition associated with the San Juan, 28.2 million years (Ma), and Silverton (27.6 Ma) calderas (Lipman and others, 1976; Bove and others, 1999) that were intruded by a 25.1 million year old, porphyritic quartz monzonite (Ringrose, 1982). The porphyritic quartz monzonite consists of plagioclase feldspar (oligoclase to andesine), biotite, alkali-feldspar, clinopyroxene, quartz, and accessory apatite and zircon (Ringrose, 1982).

All the rocks have undergone some degree of regional propylitization. This alteration, consisting of albite, epidote and chlorite \pm calcite and \pm pyrite, is described throughout the Silverton area and likely resulted from volcanically derived, carbon dioxide-rich fluids permeating the rocks along fracture surfaces (Burbanke, 1960). In the MFMC basin, the regional propylitization postdates the formation of the Silverton caldera, 27.6 Ma, because Silverton-age volcanic units have been propylitized, and predates the hydrothermal and mineralization event associated with the 25.1 Ma porphyritic quartz monzonite intrusion because this event overprints the regional propylitization.

Pervasive, zoned hydrothermal alteration is centered on Mount Moly, a prominent peak that forms the divide between Middle Fork Mineral Creek and South Fork Mineral Creek drainage basins (fig. 1). This peak is shown as peak 12,442 on the USGS Silverton Quadrangle map (1955). The alteration on and surrounding Mount Moly consists of an intense zone of quartz, sericite, pyrite, \pm pyrophyllite and \pm kaolinite (QSP) that grades outward to a weaker sericitic, quartz, montmorillonite, pyrite, and \pm kaolinite zone (WS), which in turn grades outward to the propylitically altered zone. Transitions between alteration zones become increasingly diffuse away from the center of the system. Pods and lenses of propylitically altered rocks occur within more intensely altered areas. In addition, QSP altered rocks occur adjacent to mineralized structures in the region mapped as propylitic alteration on figure 1. Mineralization is also centered on Mount Moly and consists of stockwork quartz-pyrite-molybdenite veins at higher elevations and quartz-base-metal sulfide veins along the flanks. The base-metal sulfide veins, which are localized along fractures in the volcanic units, contain sphalerite and galena with minor amounts of pyrite and tetrahedrite-tennantite. Ringrose (1982) noted that the mineralization and alteration assemblages have many features of typical Cu-Mo porphyry type mineralization as outlined by Lowell and Guilbert (1970). The area was explored and drilled by AMAX during the early 1980's but was not pursued further (Mast and others, 2000). 


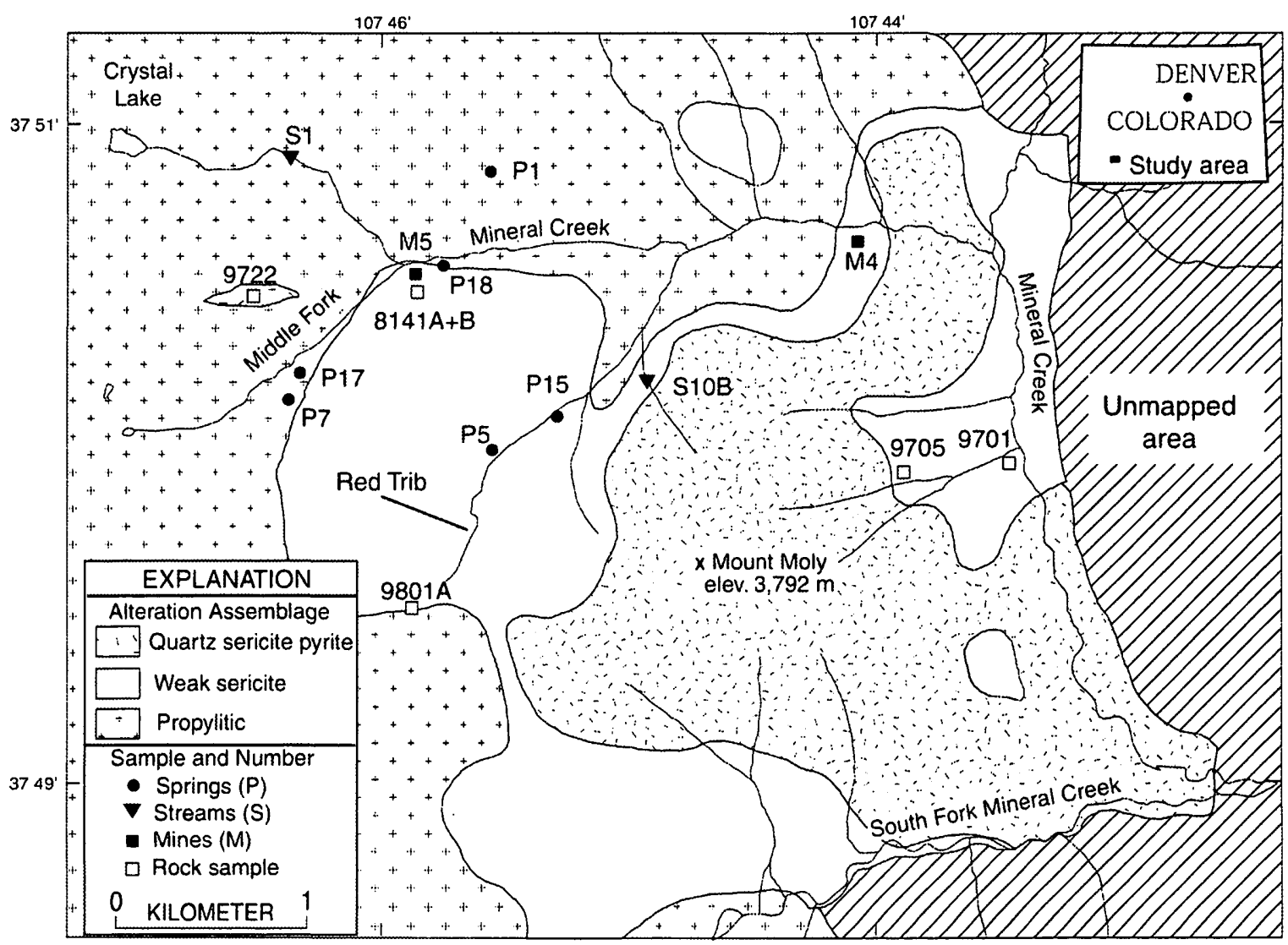

Figure 1. Location of the study area, primary geographic features, generalized alteration assemblages, and sample localities. Alteration mapping from Ringrose (1982).

\section{Sample Locations}

Seven rock samples, spanning the range in lithology and alteration in the study area, were collected to determine end-member isotopic compositions. Samples 9701 and 9705 are porphyritic quartz monzonites that have undergone propylitic and weak sericite to quartz-sericite pyrite alteration (fig. 1 ; table 1). Samples 9722, 9801A, 8141A, and 8141B are San Juan Volcanics and have also undergone hydrothermal alteration to varying degrees (fig. 1; table 1). Samples 8141A and 8141B were collected from the wasterock pile at the Paradise portal. A sample of subhedral, clear gypsum also was collected at this site; however, it is unclear whether the gypsum formed during the primary mineralization event, along the prospect drift, or on the waste-rock pile. Although sample 9722 lies within the propylitically altered region (fig. 1), it was sampled from a QSP alteration zone adjacent to a mineralized structure. 
Table 1. Selected elemental concentrations of whole-rock samples [Site locations shown in figure 1; NA, sample not analyzed for this constituent; $<$, less than]

\begin{tabular}{|c|c|c|c|c|c|c|c|}
\hline \multirow[b]{2}{*}{ Constituent } & \multicolumn{6}{|c|}{ Sample number } & \multirow[b]{2}{*}{ Gypsum } \\
\hline & 9722 & $9801 \mathrm{~A}$ & $8141 \mathrm{~A}$ & $8141 B$ & 9701 & 9705 & \\
\hline \multicolumn{8}{|c|}{ Concentration, in weight percent } \\
\hline Al & 9.7 & 9.0 & 6.0 & 8.4 & 7.9 & 7.4 & 1.2 \\
\hline $\mathrm{Ca}$ & 0.02 & 4.0 & 0.07 & 3.3 & 1.5 & 0.35 & 19 \\
\hline $\mathrm{Fe}$ & 1.8 & 6.4 & 0.50 & 5.2 & 2.6 & 2.1 & 0.60 \\
\hline K & 3.7 & 1.8 & 3.3 & 2.6 & 3.5 & 4.0 & 0.54 \\
\hline $\mathrm{Mg}$ & 0.29 & 2.8 & 0.06 & 1.1 & 0.81 & 0.45 & 0.02 \\
\hline $\mathrm{Na}$ & 0.48 & 2.2 & 0.07 & 2.4 & 2.5 & 2.0 & 0.04 \\
\hline $\mathbf{P}$ & 0.02 & 0.15 & 0.007 & 0.16 & 0.12 & 0.03 & $<0.005$ \\
\hline$\underline{\mathrm{Ti}}$ & 0.21 & 0.55 & 0.04 & 0.47 & 0.25 & 0.11 & 0.01 \\
\hline \multicolumn{8}{|c|}{ Concentration, in parts per million } \\
\hline $\mathrm{Ag}$ & $<2$ & $<2$ & $<2$ & $<2$ & $<2$ & $<2$ & $<2$ \\
\hline As & $<10$ & 25 & $<10$ & 16 & 10 & 22 & $<10$ \\
\hline $\mathrm{Au}$ & $<8$ & $<8$ & $<8$ & $<8$ & $<8$ & $<8$ & $<8$ \\
\hline $\mathrm{Ba}^{1}$ & 665 & 804 & 164 & 836 & 873 & 793 & NA \\
\hline $\mathrm{Be}$ & 1 & 1 & 3 & 1 & 2 & 2 & $<1$ \\
\hline $\mathrm{Bi}$ & $<10$ & $<10$ & $<10$ & $<10$ & $<10$ & $<10$ & $<10$ \\
\hline $\mathrm{Cd}$ & $<2$ & 3 & $<2$ & 2 & $<2$ & $<2$ & $<2$ \\
\hline $\mathrm{Ce}$ & 60 & 80 & 19 & 79 & 94 & 89 & 42 \\
\hline Co & 5 & 26 & 2 & 20 & 9 & 9 & 2 \\
\hline $\mathrm{Cr}$ & 18 & 29 & $<1$ & 4 & 1 & $<1$ & $<1$ \\
\hline $\mathrm{Cu}$ & 3 & $<1$ & 1 & 50 & 19 & 59 & 4 \\
\hline Eu & $<2$ & $<2$ & $<2$ & 2 & $<2$ & $<2$ & $<2$ \\
\hline $\mathrm{Ga}$ & 20 & 18 & 16 & 13 & 14 & 13 & $<4$ \\
\hline Ho & $<4$ & $<4$ & $<4$ & $<4$ & $<4$ & $<4$ & $<4$ \\
\hline $\mathrm{La}$ & 32 & 43 & 11 & 40 & 52 & 49 & 26 \\
\hline $\mathrm{Li}$ & 18 & 37 & 380 & 14 & 14 & 9 & 2 \\
\hline Mn & 20 & 1,200 & 170 & 1,200 & 360 & 120 & 27 \\
\hline Mo & $<2$ & $<2$ & 39 & $<2$ & 12 & 7 & $<2$ \\
\hline $\mathrm{Nb}$ & 21 & 18 & 88 & 16 & 21 & 13 & $<4$ \\
\hline $\mathrm{Nd}$ & 23 & 38 & $<4$ & 38 & 39 & 35 & 18 \\
\hline $\mathrm{Ni}$ & 3 & 17 & $<2$ & 9 & 6 & 6 & 2 \\
\hline $\mathrm{Pb}$ & 61 & 16 & 46 & 14 & 42 & 780 & 13 \\
\hline $\mathrm{Sc}$ & 19 & 25 & 3 & 15 & 9 & 5 & $<2$ \\
\hline $\mathrm{Sn}$ & $<5$ & $<5$ & $<5$ & $<5$ & $<5$ & $<5$ & $<5$ \\
\hline $\mathrm{Sr}$ & 120 & 490 & 35 & 650 & 570 & 260 & 2,200 \\
\hline Ta & $<40$ & $<40$ & $<40$ & $<40$ & $<40$ & $<40$ & $<40$ \\
\hline Th & $<4$ & $<4$ & 38 & $<4$ & 29 & 20 & $<4$ \\
\hline $\mathrm{U}$ & $<100$ & $<100$ & $<100$ & $<100$ & $<100$ & $<100$ & $<100$ \\
\hline V & 200 & 180 & 3 & 100 & 69 & 53 & 10 \\
\hline Y & 2 & 22 & 9 & 27 & 20 & 10 & 13 \\
\hline $\mathrm{Yb}$ & $<1$ & 2 & 2 & 2 & 2 & $<1$ & 1 \\
\hline $\mathrm{Zn}$ & $<2$ & 170 & 14 & 76 & 34 & 44 & 6 \\
\hline $\mathrm{Rb}^{1}$ & 134 & 68 & 370 & 89 & 132 & 181 & NA \\
\hline $\mathrm{Sr}^{1}$ & 155 & 445 & 37 & 673 & 569 & 270 & $\mathrm{NA}$ \\
\hline
\end{tabular}

Element determined by energy-dispersive X-ray flouresence. 
Ten water samples were collected during low-flow of 1995 that include stream sites (S1 and S10B), springs (P1, P5, P7, P15, P17, and P18), and adit effluent (M4 and M5, fig. 1). Sample designations are the same as in Mast and others (2000), with the exception of stream sample S10B, which corresponds to a September 1995 sampling at the same site as S10. Sample S1, downstream from Crystal Lake at an elevation of $3674 \mathrm{~m}$ at the highest location sampled, is surrounded by propylitically altered San Juan Volcanics. Sample P1 was a small spring that emanated from propylitically altered volcanic lithologies along the north side of the basin. Sample S10B was from a small tributary that emanated from a large colluvial fan on the northwest flank of Mount Moly. The fan consists primarily of intensely altered quartz monzonite (Yager and others, 2000). Springs P7 and P17 were from Paradise basin and are primarily within San Juan Volcanics, although a couple of small quartz monzonite stocks crop out in the vicinity. Sample P18 was from a spring along MFMC just east of Paradise Portal. Samples P5 and P15 were from springs along a stream informally called the Red Trib, with P5 on the west side and P15 on the east side. Sample M4 was from an acidic seep near the base of the waste-rock pile below the lower caved adit of the Bonner mine, an active mine in the late 1800's. Ore was mined from a base metal sulfide vein associated with the quartz monzonite mineralization (Ransome, 1901). Sample M5 was taken from adit effluent at Paradise portal. The effluent discharged from a caved adit at the upper edge of a waste-rock pile that rests on a steep slope approximately $25 \mathrm{~m}$ above the MFMC, and the effluent cascaded down the waste-rock pile coating the rocks with a white precipitate, which is an amorphous aluminum hydroxysulfate (Bigham and Nordstrom, 2000).

\section{Acknowledgments}

The work by Philip Verplanck was funded in part by the National Research Council's post-doctoral research program. The authors would like to thank G. Lang Farmer for the use of his radiogenic isotope laboratory at the University of Colorado, Boulder. Reviews by S.E. Church, M.A. Mast, D.K. Nordstrom, and J.V. Flager greatly improved the manuscript.

\section{METHODS OF STUDY}

Water temperature, $\mathrm{pH}$, and specific conductance were determined on site. Samples for major and trace constituents and strontium isotopic analyses were field filtered through 0.45 micrometer $(\mu \mathrm{m})$-poresize canister filters and acidified with ultrapure nitric acid to a $\mathrm{pH}$ value of less than 2 . The chemical compositions of these waters are published in Mast and others (2000). Strontium isotopic compositions of water samples (table 2) were determined using a Finnigan MAT 261, six-collector solid-source mass spectrometer at the University of Colorado, Boulder, using procedures described in Farmer and others (1991).

Samples of bedrock were analyzed to characterize the range in chemical and strontium isotopic ratios. Samples were crushed and powdered, and aliquots were split for whole-rock analyses and leaching. Three grams of each powdered sample were leached with 90 milliliters $(\mathrm{mL})$ of 0.01 molar sulfuric acid for 1,4 , 8 , and 24 hours at room temperature. Because of the disseminated pyrite throughout the study area and the numerous occurrences of acidic springs, using a dilute sulfuric acid leach is more appropriate than using distilled water or dilute hydrochloric acid, traditional leach media. Samples were agitated gently during the entire leach period. Ten $\mathrm{mL}$ aliquots of leachate were extracted; the solutions were centrifuged, and the supernatant removed for analysis and the solids returned to bottle. Major and trace elements were determined for each leachate by inductively coupled plasma-atomic emission spectroscopy (ICP-AES) following procedures described in Briggs (1996; table 3). Many trace elements analyzed were below the detection limit (in milligrams per liter-mg/L) including cadmium (20), chromium (10), cobalt (10), molybdenum (20), nickel (10), and titanium (50). Strontium isotopic compositions of selected leachates were determined using an Isomass-54R mass spectrometer at the USGS laboratory in Denver, Colorado 
(table 4). Detailed descriptions of analytical methods are given in Church and others (2000). Whole-rock elemental concentrations were determined by ICP-AES and energy-dispersive X-ray fluorescence (table 1 and appendix 1), and strontium isotopic ratios were determined with the same analytical procedures as those used for the leachates. The suite of altered samples in appendix 1 was used to guide the selection of the samples for leaching.

All ${ }^{87} \mathrm{Sr} /{ }^{86} \mathrm{Sr}$ ratios reported in this text are the measured ratio, unless otherwise stated as the initial ratio. The initial ratio of a rock sample, the strontium isotopic value at the time of formation, is calculated using a radioactive decay equation. Using the age of the sample and the rubidium to strontium ratio, the amount of ${ }^{87} \mathrm{Sr}$ created by the decay of ${ }^{87} \mathrm{Rb}$ (since the rock formed) is subtracted from the measured ${ }^{87} \mathrm{Sr} /{ }^{86} \mathrm{Sr}$ ratios to yield the ${ }^{87} \mathrm{Sr} /{ }^{86} \mathrm{Sr}$ ratio at the time of rock formation (Faure, 1986). This calculated ratio assumes that the age of the rock is known and that the rubidium-strontium ratio has not changed since the age of formation.

Table 2. Selected characteristics of water samples

[mg/L, milligrams per liter; $\mu \mathrm{S} / \mathrm{cm}$, microsiemens per centimeter at $25^{\circ} \mathrm{C} ; 2 \sigma$, two sigma]

\begin{tabular}{|c|c|c|c|c|c|c|c|}
\hline $\begin{array}{c}\text { Sample } \\
\text { number } \\
\text { (fig. 1) }\end{array}$ & $\begin{array}{c}\text { Elevation } \\
\text { (meters) }\end{array}$ & $\begin{array}{c}\text { pH, } \\
\text { (standard } \\
\text { units) }\end{array}$ & $\begin{array}{c}\text { Specific } \\
\text { conductance } \\
(\mu \mathrm{S} / \mathrm{cm})\end{array}$ & $\begin{array}{l}\text { Calcium, } \\
\text { dissolved } \\
\text { (mg/L as } \\
\text { Ca) }\end{array}$ & $\begin{array}{l}\text { Strontium, } \\
\text { dissolved } \\
\text { (mg/L as } \\
\text { Sr) }\end{array}$ & $\begin{array}{l}{ }^{87} \mathrm{Sr} /{ }^{86} \mathrm{Sr}, \\
\text { dissolved }\end{array}$ & 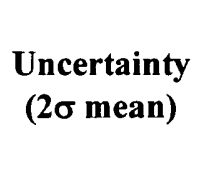 \\
\hline $\mathrm{S} 1$ & 3,475 & 4.47 & 59.5 & 3.5 & 0.028 & 0.70760 & 0.00001 \\
\hline S10B & 3,182 & 3.12 & 881 & 20 & 0.23 & 0.70699 & 0.00001 \\
\hline P1 & 3,304 & 6.56 & 106 & 17 & 0.086 & 0.70773 & 0.00004 \\
\hline P5 & 3,414 & 5.40 & 214 & 21 & 0.18 & 0.70808 & 0.00001 \\
\hline $\mathrm{P} 7$ & 3,401 & 6.84 & 451 & 82 & 0.96 & 0.70808 & 0.00001 \\
\hline P15 & 3,316 & 3.06 & 1480 & 280 & 2.4 & 0.70744 & 0.00001 \\
\hline P17 & 3,414 & 5.72 & 1850 & 420 & 5.7 & 0.70816 & 0.00001 \\
\hline P18 & 3,273 & 6.43 & 2180 & 550 & 4.7 & 0.70899 & 0.00001 \\
\hline M4 & 3,048 & 3.12 & 970 & 110 & 0.47 & 0.70654 & 0.00002 \\
\hline M5 & 3,249 & 5.70 & 1960 & 400 & 2.7 & 0.70853 & 0.00001 \\
\hline
\end{tabular}




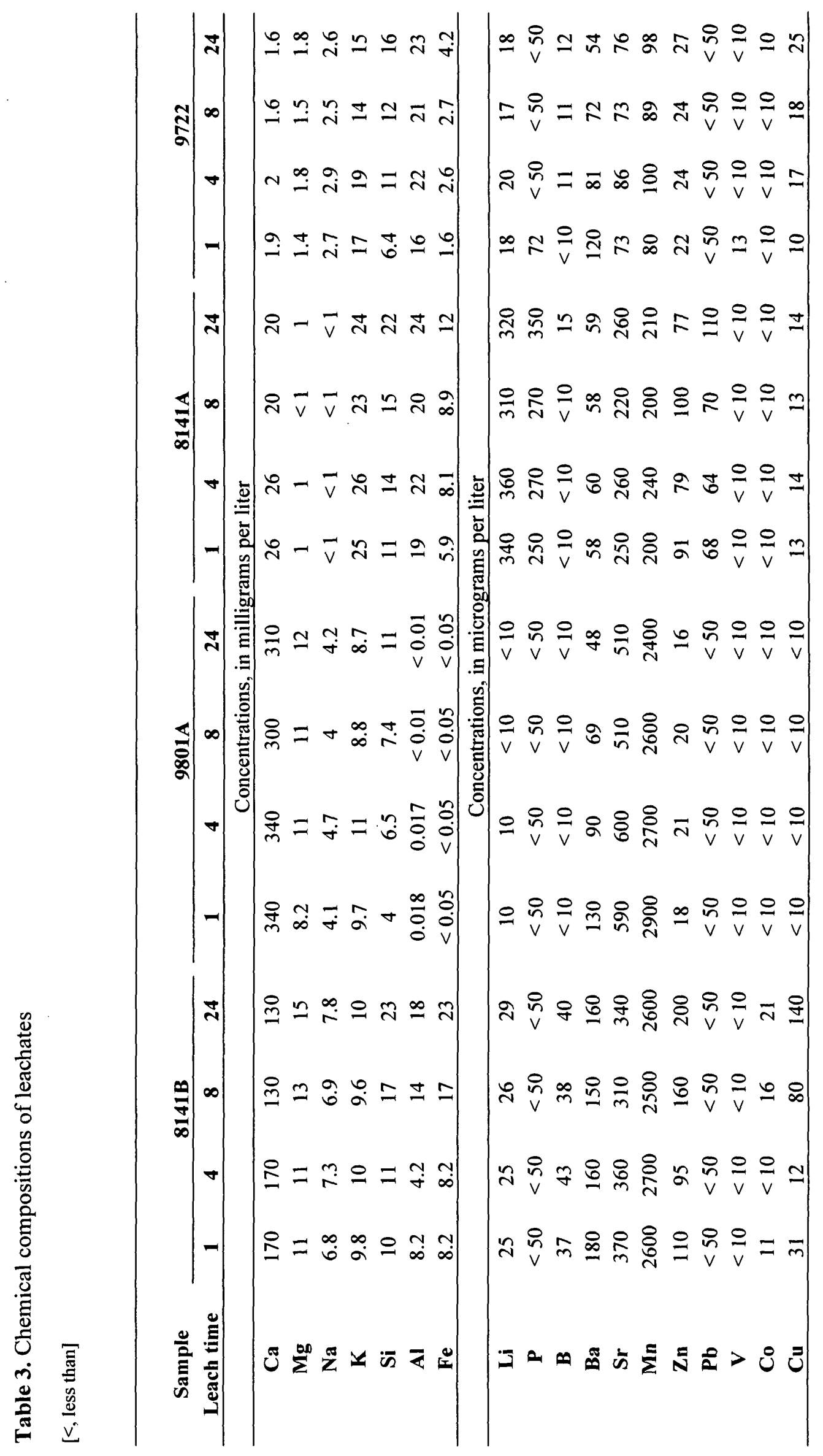




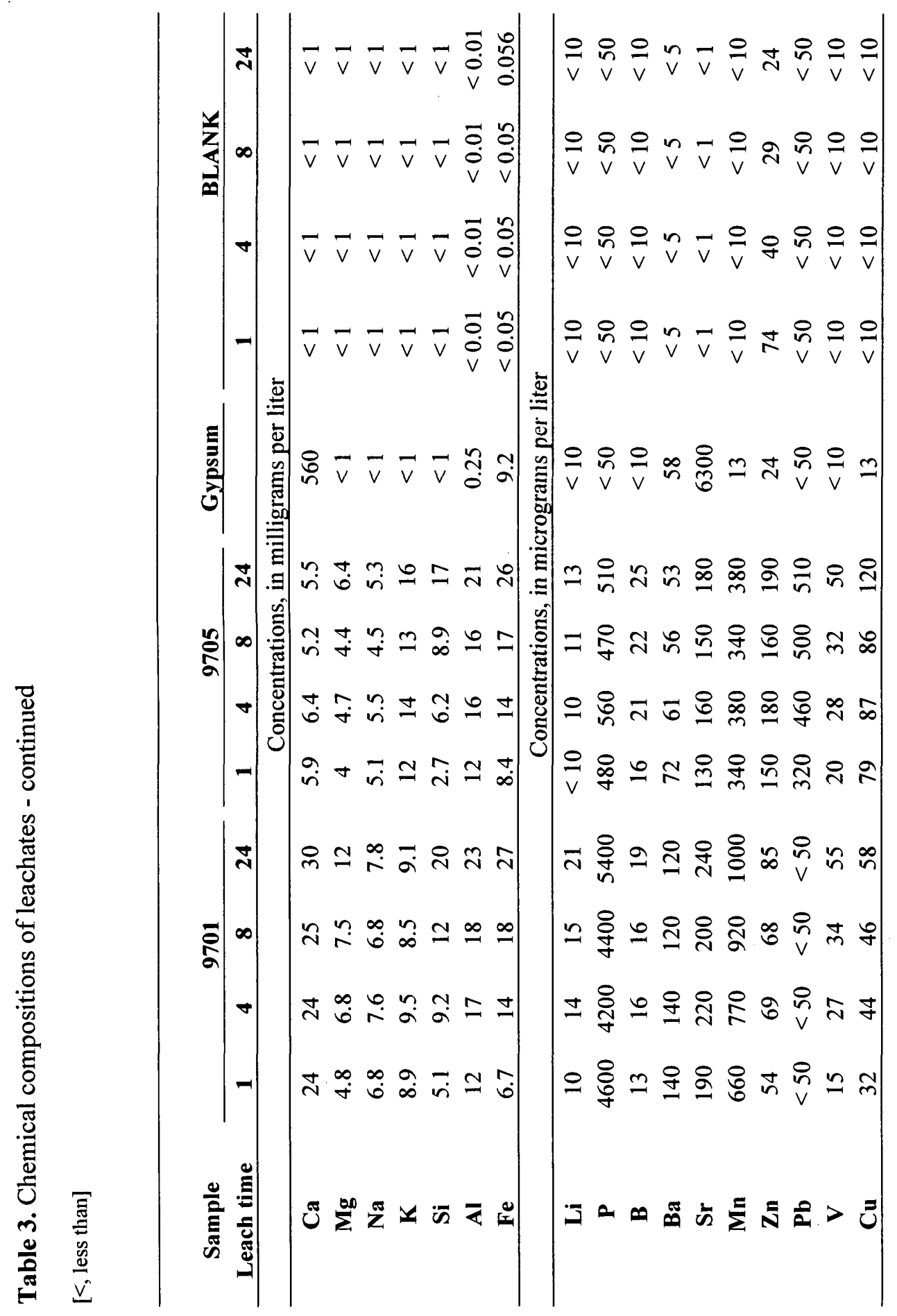




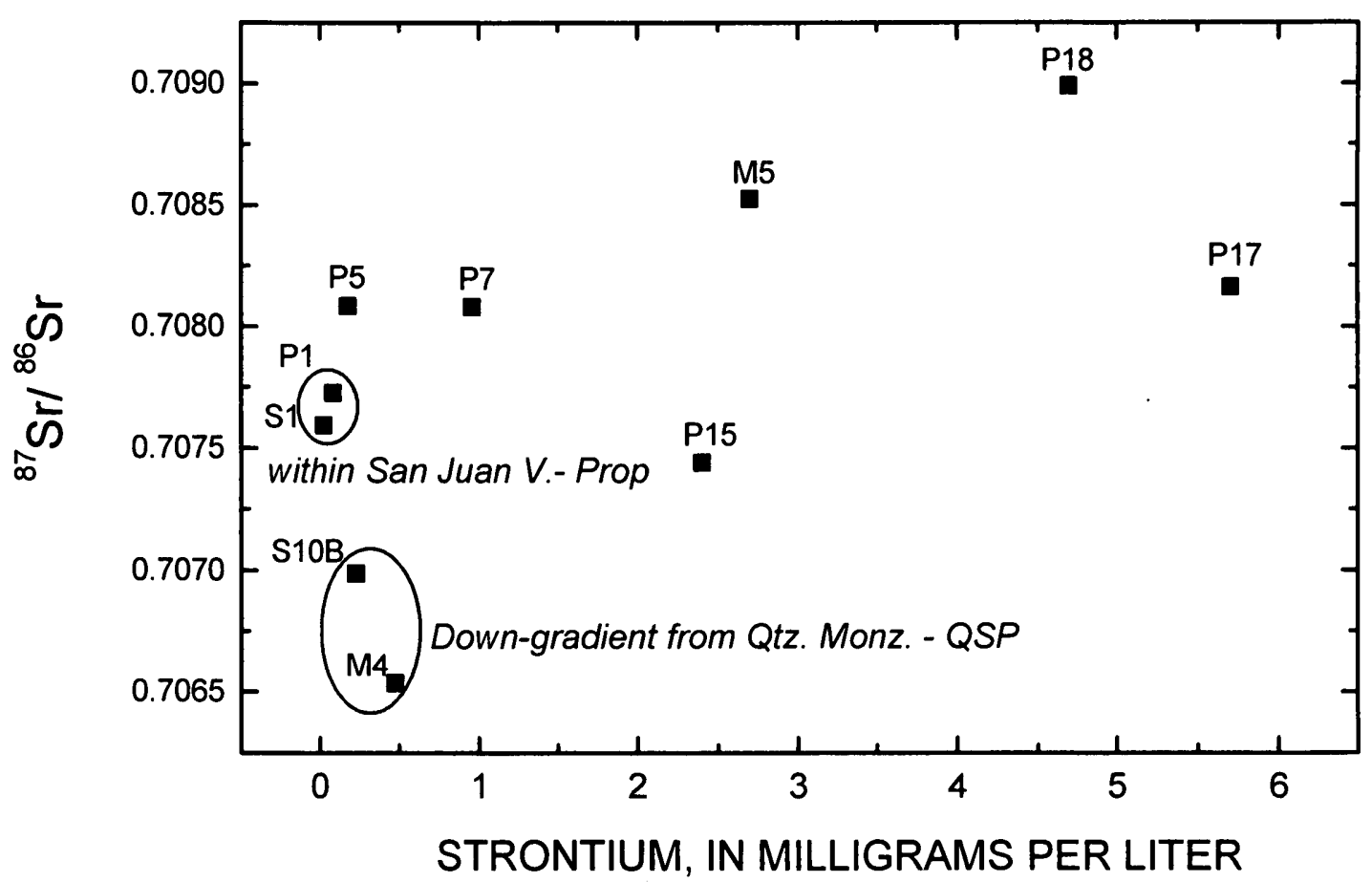

Figure 2. Relation between ${ }^{87} \mathrm{Sr} /{ }^{86} \mathrm{Sr}$ ratio and strontium concentration of water samples.

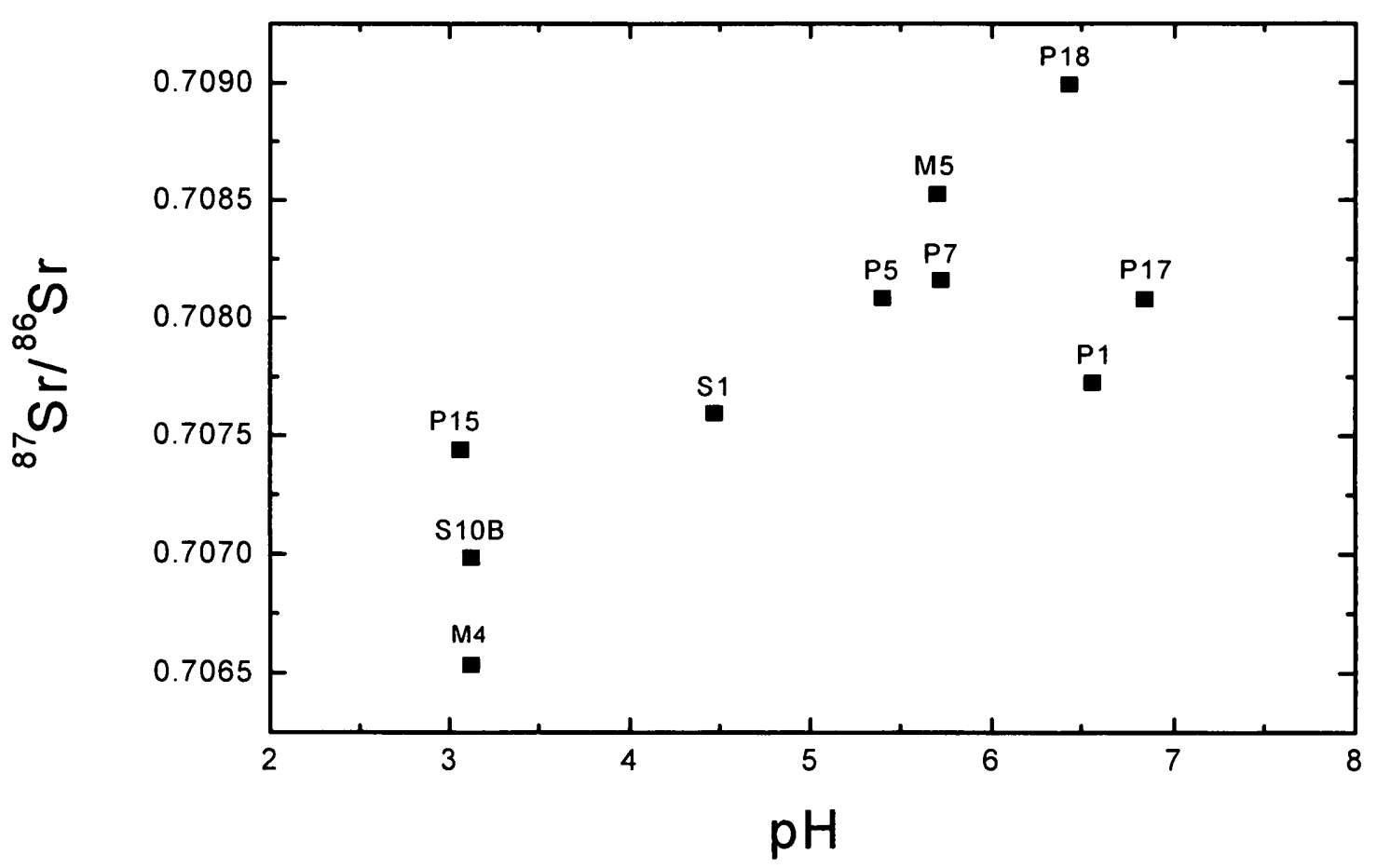

Figure 3. Relation between ${ }^{87} \mathrm{Sr} /{ }^{86} \mathrm{Sr}$ ratio and $\mathrm{pH}$ value of water samples. 


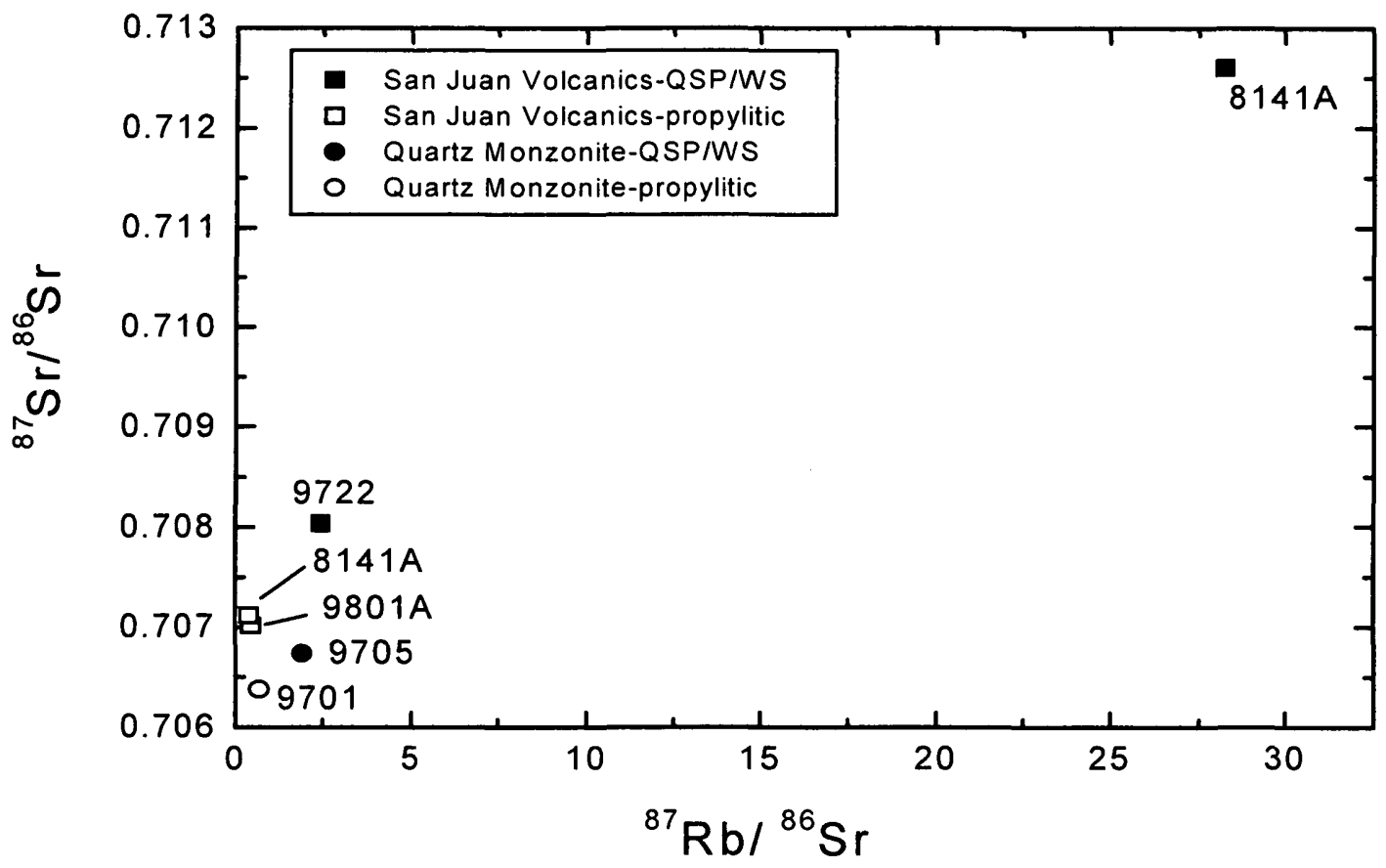

Figure 4. Relation between ${ }^{87} \mathrm{Sr} /{ }^{86} \mathrm{Sr}$ ratio and ${ }^{87} \mathrm{Rb} /{ }^{86} \mathrm{Sr}$ ratio for whole-rock samples.

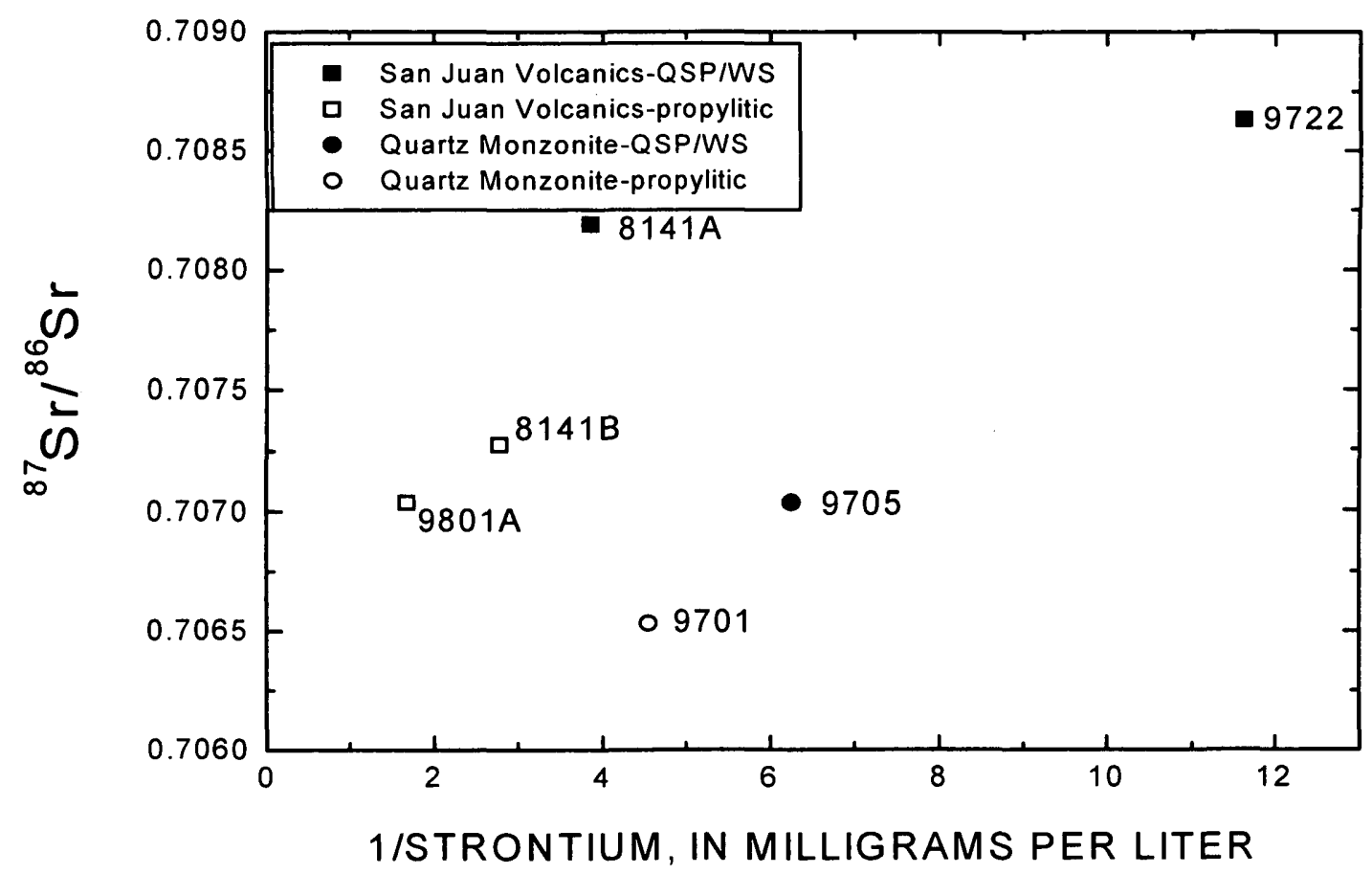

Figure 5. Relation between ${ }^{87} \mathrm{Sr} /{ }^{86} \mathrm{Sr}$ ratio and $1 / \mathrm{Sr}$ concentration of 4-hour leachates. 


\section{RESULTS OF CHEMICAL ANALYSES}

Acidic waters in the MFMC basin are produced by pyrite oxidation of mined and unmined mineralized rock. Naturally-occurring acid springs ( $\mathrm{pH}$ 2.7-6.8) and acid mine drainage ( $\mathrm{pH}$ 2.3-6.4) dissolve minerals in the country rock and release strontium, predominantly derived from calcite, epidote, and plagioclase (Mast and others, 2000).

The ten water samples analyzed had strontium concentrations that ranged from 0.028 to $5.7 \mathrm{mg} / \mathrm{L}$ and ${ }^{87} \mathrm{Sr} /{ }^{86} \mathrm{Sr}$ ratios from 0.70654 to 0.70899 (table 2). Variation in the ${ }^{87} \mathrm{Sr} /{ }^{86} \mathrm{Sr}$ ratios of the water samples does not correlate with strontium concentration (fig. 2) but does correlate with the pH (fig. 3). Samples with lower ${ }^{87} \mathrm{Sr} /{ }^{86} \mathrm{Sr}$ ratios are the more acidic, and samples with higher ${ }^{87} \mathrm{Sr} /{ }^{86} \mathrm{Sr}$ ratios tend to be less acidic. Spatially, the samples with the lower isotopic ratios (P15, S10B, and M4) are located along the flanks of Mount Moly down-gradient from the zone of QSP alteration (fig. 1).

The strontium isotopic compositions of six rock samples were analyzed to determine if the isotopic composition varies with lithology or alteration assemblage. The measured whole-rock ${ }^{87} \mathrm{Sr} /{ }^{86} \mathrm{Sr}$ ratios vary from 0.70638 to 0.71261 (table 4). The two samples of the quartz monzonite porphyry had the lowest ${ }^{87} \mathrm{Sr} /{ }^{86} \mathrm{Sr}$ ratios, less than 0.70674 . For a given lithology, the propylitically altered samples had lower strontium isotopic ratios and higher strontium concentrations (table 4), and the more intensely altered samples have higher ${ }^{87} \mathrm{Sr} /{ }^{86} \mathrm{Sr}$ and ${ }^{87} \mathrm{Rb} /{ }^{86} \mathrm{Sr}$ ratios (fig. 4). The initial ${ }^{87} \mathrm{Sr} /{ }^{86} \mathrm{Sr}$ ratios of the quartz monzonite samples, calculated at $25.1 \mathrm{Ma}$ (the age of the quartz monzonite intrusion and the hydrothermal event), are 0.70607 and 0.70615 , and the ratios for three of the four San Juan volcanic rock samples range from 0.70687 to 0.70717 . These values are similar to previously reported values for the San Juan and Silverton Volcanics, 0.7071 and 0.7075 (Lipman and others, 1978). The initial ${ }^{87} \mathrm{Sr} /{ }^{86} \mathrm{Sr}$, calculated at $25.1 \mathrm{Ma}$, of sample 8141A, a San Juan volcanic sample collected from the Paradise Portal waste-rock pile, is 0.70255 . This value is significantly lower than any other continental volcanic unit, and likely reflects loss of strontium. The whole-rock strontium concentration, 37 parts per million (ppm), is lower than any other sample in the MFMC study area (table 4, Appendix 1). Loss of strontium likely occurred when the sample was exposed to acidic drainage flowing on the waste-rock pile; thus, the calculated initial ratio likely is lower than the actual initial ratio.

The gypsum crystal from the Paradise portal waste-rock pile has the highest strontium concentration $(2,200 \mathrm{ppm})$ of any solid phase analyzed. The strontium isotopic ratio $(0.70749)$ is slightly higher than the propylitically altered San Juan volcanic sample (8141B) collected at the same waste-rock pile (0.70712).

Leach experiments were performed to quantify the concentration and isotopic ratio of the more easily weathered strontium from the bedrock. Similar to the whole-rock samples, the 4-hour leachates of quartz monzonite samples had lower ${ }^{87} \mathrm{Sr} /{ }^{86} \mathrm{Sr}$ ratios, 0.70653 and 0.70704 , than the 4-hour leachates from the San Juan volcanic samples, 0.70704 to 0.70863 . For a given lithology, the leachates from the propylitically altered samples also had lower ${ }^{87} \mathrm{Sr} /{ }^{86} \mathrm{Sr}$ ratios and higher strontium concentrations than the more intensely altered rocks (fig. 5). With the exception of sample 8141A, the 4-hour leachates had slightly higher ${ }^{87} \mathrm{Sr} /{ }^{86} \mathrm{Sr}$ ratios than their corresponding whole-rock samples. For two samples, strontium isotopic ratios and concentrations were determined on the 4- and 24-hour leachates to see if the longer leach times caused different results. The results were virtually identical for the propylitically altered San Juan volcanic sample, 8141B (table 4). The 24-hour leachate of the more intensely altered San Juan volcanic sample, 9722 , had a slightly lower strontium concentration and lower ${ }^{87} \mathrm{Sr} /{ }^{86} \mathrm{Sr}$ ratio, approaching that of the whole-rock isotopic value (table 4).

The chemical compositions of the leachates were determined to compare the more easily weathered constituents from different lithologies and alteration assemblages (table 3). For a given lithology, the barium, calcium, magnesium, manganese, and strontium concentrations of the propylitically altered 
samples were greater than for the more intensely altered samples, and aluminum and potassium concentrations were lower. Similar concentration variations also generally existed in the whole-rock samples (tables 1 and 3). Leaching with dilute sulfuric acid, $\mathrm{pH} \sim 2.5$, not only removes the easily exchangeable strontium, but also may dissolve the more easily weathered minerals, particularly calcite. The relatively high calcium concentration of the propylitic rock leachates, compared to leachates from the more intensely altered samples, indicates that the calcium-rich phases in the propylitically altered samples are being dissolved. For the leachate samples, the aluminum, iron, and silica concentrations generally increased with increasing leach time, and the other elemental concentrations remain nearly constant.

Table 4. Strontium isotopic compositions of whole-rock and leachate samples

[hrs, hours; ng, nanogram; ---, sample not analyzed for this constituent; <, less than; $2 \sigma$, two sigma]

\begin{tabular}{|c|c|c|c|c|c|c|c|}
\hline $\begin{array}{c}\text { Sample number } \\
\text { (fig. 1) }\end{array}$ & $\begin{array}{c}\text { Rock unit } \\
\text { (alteration } \\
\text { assemblage) }\end{array}$ & $\begin{array}{c}\text { Leach } \\
\text { time }^{1} \\
\text { (hrs) }\end{array}$ & $\begin{array}{c}\text { Strontium } \\
\text { concentration }\end{array}$ & $\begin{array}{l}\text { Rubidium } \\
\text { concentration }^{2}\end{array}$ & ${ }^{87} \mathrm{Sr} /{ }^{86} \mathrm{Sr}(\mathrm{m})$ & 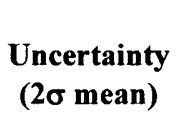 & $\underset{{ }^{87} \mathrm{Sr} /{ }^{86} \mathrm{Sr}}{\text { Inial }^{3}}$ \\
\hline \multirow[t]{3}{*}{$8141 B$} & San Juan Volcanic & WR & 673 & 89 & 0.70712 & 0.000015 & 0.70698 \\
\hline & (Propylitic) & 4 & 0.36 & -- & 0.70727 & 0.00002 & \\
\hline & & 24 & 0.34 & -- & 0.70727 & 0.00003 & \\
\hline \multirow[t]{2}{*}{$9801 \mathrm{~A}$} & San Juan Volcanic & WR & 445 & 68 & 0.70702 & 0.00002 & 0.70687 \\
\hline & (Propylitic) & 4 & 0.6 & -- & 0.70704 & 0.00002 & \\
\hline $8141 \mathrm{~A}$ & San Juan Volcanic & WR & 37 & 370 & 0.71261 & 0.00005 & 0.70255 \\
\hline \multirow[t]{2}{*}{ 8141A-duplicate } & (QSP) & WR & 35 & -- & 0.71261 & 0.00002 & 0.70255 \\
\hline & & 4 & 0.26 & - & 0.70819 & 0.00002 & \\
\hline \multirow[t]{3}{*}{9722} & San Juan Volcanic & WR & 155 & 134 & 0.70804 & 0.00002 & 0.70717 \\
\hline & (QSP) & 4 & 0.086 & -- & 0.70863 & 0.00002 & \\
\hline & & 24 & 0.076 & -- & 0.70809 & 0.00003 & \\
\hline \multirow[t]{2}{*}{9701} & Qtz Monzonite & WR & 569 & 132 & 0.70638 & 0.00002 & 0.70615 \\
\hline & (Propylitic) & 4 & 0.22 & -- & 0.70653 & 0.00002 & \\
\hline \multirow[t]{2}{*}{9705} & Qtz Monzonite & WR & 270 & 181 & 0.70674 & 0.00002 & 0.70607 \\
\hline & (QSP/Weak Sericitic) & 4 & 0.16 & -- & 0.70704 & 0.00002 & \\
\hline Gypsum & & & 2200 & -- & -- & -- & \\
\hline Gypsum leachate $^{4}$ & & & 6.3 & -- & 0.70749 & 0.00002 & \\
\hline Chemical blank & & & $<2 \mathrm{ng}$ & -- & & & \\
\hline Leach blank & & & $0.1 \mathrm{ng} / \mathrm{mL}$ & -- & & & \\
\hline
\end{tabular}

I WR-whole-rock.

${ }^{2}$ Whole-rock concentration in parts per million, leachate concentration in milligrams per liter.

${ }^{3}$ Whole-rock strontium initial isotope ratio calculated at $25.1 \mathrm{Ma}$, and $\lambda=1.42 \times 10^{-11}$.

${ }^{4}$ Gypsum completely dissolved in first leaching. 


\section{EVALUATION OF STRONTIUM ISOTOPES AS A GEOCHEMICAL TRACER}

This section of the report evaluates the possible use of strontium isotopic ratios to determine sources and flow paths in the MFMC basin. First, the isotopic compositions of the source lithologies are described. Then, possible flow paths are proposed.

\section{Sources}

To successfully use the strontium isotopic ratios of water samples to identify hydrologic flow paths and solute sources, the isotopic compositions of the lithologies along the flow paths must be distinct. Results from this study demonstrate that the variation in the whole-rock strontium isotopic ratios correlate with variations in lithology and alteration intensity; the two quartz monzonite samples $\left({ }^{87} \mathrm{Sr} /{ }^{86} \mathrm{Sr}=\right.$ 0.70638 and 0.70674 ) have lower isotopic ratios than the four San Juan volcanic samples $\left({ }^{87} \mathrm{Sr} /{ }^{86} \mathrm{Sr}=\right.$ 0.70702 to 0.71261 ) and for a given lithology the propylitically altered samples have lower strontium isotopic ratios than the more intensely altered samples. With this limited data set, it is difficult to address potential variations in underlying magmatic source regions, but a similar shift to lower strontium isotopic ratios with age (older at 27.8 to $26.9 \mathrm{Ma}$ and younger at 26.4 to $26.1 \mathrm{Ma}$ ) has been described by Riciputi and others (1995) for volcanic units in the central San Juan volcanic field. They interpreted the shift to less radiogenic values, lower ${ }^{87} \mathrm{Sr} /{ }^{86} \mathrm{Sr}$ ratios, to a fundamental change in the magmatic source area. The isotopic shift likely reflects hybridization of the upper and lower crust by mantle-derived melts. Crustal rocks tend to have higher ${ }^{87} \mathrm{Sr} /{ }^{86} \mathrm{Sr}$ ratios (greater than 0.706) and mantle material tends to have lower ${ }^{87} \mathrm{Sr} /{ }^{86} \mathrm{Sr}$ ratios $(\sim 0.704)$. Addition of mantle material to the crust lowers the crustal strontium isotopic ratio, and magmas produced from this hybrid area would reflect to lower ${ }^{87} \mathrm{Sr} /{ }^{86} \mathrm{Sr}$ ratios.

The propylitically altered samples have consistently higher calcium and strontium concentrations, as well as lower potassium and rubidium concentrations, than the more intensely altered samples. Detailed studies of large porphyry systems have documented similar changes in whole-rock chemistry with alteration assemblage (Grant, 1986; Farmer and DePaulo, 1987; Baumgartner and Olsen, 1995). At San Manuel, Arizona, Farmer and DePaulo (1987) determined that the phyllic zone (quartz-sericite-pyrite alteration assemblage) was depleted in strontium relative to the outer propylitic zone. Furthermore, Ringrose (1982) undertook a surface sampling survey of the MFMC study area and found that in general the variation in the rubidium-strontium ratio correlated with alteration assemblage, and the QSP altered samples had higher ratios than the propylitically altered samples. With time, the higher rubidiumstrontium ratio of the more intensely altered lithologies leads to higher ${ }^{87} \mathrm{Sr} /{ }^{56} \mathrm{Sr}$ (Farmer and DePaolo, 1987).

Overall, the strontium isotopic ratios of the whole-rock samples from different alteration suites are distinct, but the isotopic contrast between the suites is small. Although there is a range in rubidiumstrontium ratios, the rock samples are young compared to the half-life of ${ }^{87} \mathrm{Rb}, 48.8 \times 10^{9}$ years, and thus the decay of ${ }^{87} \mathrm{Rb}$ to form ${ }^{87} \mathrm{Sr}$ has not occurred over a long enough period of time to produce large differences in the ${ }^{87} \mathrm{Sr} /{ }^{56} \mathrm{Sr}$ ratios.

\section{Flow Paths}

The complex geologic history of the MFMC study area poses a challenge for the application of strontium isotopes for defining the hydrologic flow paths. Variations in the bedrock geology, intensity of hydrothermal alteration, and extent of mineralization affect not only the strontium isotopic systematics, but also the acidity, which controls the rate of weathering. In addition, the rugged terrain leads to both short and long flow paths, which govern the time the water has to interact with various lithologies. Results from the leach tests provide a foundation for determining water compositions along different flow 
paths. Using results from the leach tests, the range in water compositions, and knowledge of the upgradient lithologic variations, scenarios for ground-water chemical evolution can be hypothesized for different flow paths (fig. 6). For this exercise, QSP and propylitically altered San Juan Volcanics and quartz monzonite were evaluated, and weak sericitic alteration was omitted because it is intermediate between the two end member alteration assemblages.

Precipitation in the study area was not sampled, but a 1994 study in Loch Vale, Colorado in Rocky Mountain National Park determined that chemistry of the precipitation was extremely dilute (Clow and others, 1997). Strontium concentrations of snow samples were near the detection limit of $0.0004 \mathrm{mg} / \mathrm{L}$ and had an ${ }^{87} \mathrm{Sr} /{ }^{86} \mathrm{Sr}$ ratio of 0.7113 . The bulk rain averaged $0.0026 \mathrm{mg} / \mathrm{L}$ strontium and an ${ }^{87} \mathrm{Sr} /{ }^{86} \mathrm{Sr}$ ratio of 0.7121 (Clow and others, 1997). In the current study, the most dilute sample (S1, downstream from an alpine lake) was obtained to try to estimate the isotopic composition of precipitation. The strontium concentration $(0.028 \mathrm{mg} / \mathrm{L})$ is significantly higher than the concentration for precipitation measured at Loch Vale, suggesting that the stream water has interacted with the surrounding propylitically altered volcanics, shifting the strontium isotopic ratio towards a value approaching the propylitic volcanic value. Furthermore, the calcium concentration of sample S1 $(3.5 \mathrm{mg} / \mathrm{L}$, table 2$)$ is greater than the annual volume-weighted mean concentrations measured at a precipitation monitoring station twelve kilometers to the south (Molas Pass; $0.18 \mathrm{mg} / \mathrm{L} \mathrm{Ca}$; http://nadp.sws.uiuc.edu.). Because of the significantly greater concentrations of calcium and strontium in the sample compared to precipitation, the ${ }^{87} \mathrm{Sr} /{ }^{86} \mathrm{Sr}$ ratio of this water sample cannot be used as an estimate for local precipitation. This sample may represent expected surface water values of precipitation that has had a short residence time in propylitically altered volcanics; although a significant change in solute concentrations occurred, the $\mathrm{pH}$ value (4.47) of the stream water is much more similar to local precipitation (4.76 to 5.01 from 1994 to 1999; http://nadp.sws.uiuc.edu) than to springs that drain propylitically altered volcanics at lower elevations in the MFMC basin (pH values of 5.72 to $6.84 ; \mathrm{P} 7, \mathrm{P} 17$, and P18, table 2).

Sample P1, a spring within the propylitically altered San Juan Volcanics, has similar elemental and isotopic compositions to $\mathrm{S} 1$ but higher $\mathrm{pH}$ and calcium content (table 2). This sample likely represents a shallow ground water within the propylitic assemblage. These two dilute waters samples had higher ${ }^{87} \mathrm{Sr} /{ }^{86} \mathrm{Sr}$ ratios $(0.70760-0.70773)$ than the leachate from the propylitic samples $(0.70704$ and 0.70727 ; 8141B and 9801A, table 4). The slightly different strontium isotopic ratios may represent sample heterogeneity or may result from the dilute spring water being less reactive than the sulfuric acid leach water.

Water interacting with QSP altered rocks leads to much different compositions than water interacting with propylitically altered units (Mast and others, 2000). Not only does the oxidation of pyrite produce acidic water, but this hydrothermal alteration assemblage contains few minerals that would tend to neutralize the acidity. In contrast to the flow paths within the propylitically altered lithologies, the $\mathrm{pH}$ value of the water will likely decrease with longer residence time in the QSP zone (fig. 6). Results from the leaching experiments demonstrate that the strontium concentration is lower in the QSP than in the propylitically altered samples, and for a given lithology the ${ }^{87} \mathrm{Sr} /{ }^{86} \mathrm{Sr}$ is higher. Although the results from leaching experiments can be used as a tool for guiding interpretations, caution is needed when extrapolating these results to the scale of a drainage basin (Smith and others, 2000). No springs were sampled within the QSP zone, but spring samples within or down gradient from weak sericitically altered San Juan volcanic units (P5, P17, P17, and P18) had ${ }^{87} \mathrm{Sr} /{ }^{86} \mathrm{Sr}$ ratios greater than 0.7080 , reflecting the higher strontium isotopic ratio of the more intensely altered units.

The two samples (M4 and S10B) with the lowest ${ }^{87} \mathrm{Sr} /{ }^{86} \mathrm{Sr}$ lie within the most intensely altered quartz monzonite porphyry, again demonstrating that the strontium isotopic composition reflects the ${ }^{87} \mathrm{Sr} /{ }^{86} \mathrm{Sr}$ of the units along the flow path. Sample M4 is from a seep below the largest mine in the study area, and sample $\mathrm{S} 10 \mathrm{~B}$ is up-gradient of any mining activity. The $\mathrm{pH}$ values, strontium concentrations, and ${ }^{87} \mathrm{Sr} /{ }^{86} \mathrm{Sr}$ 


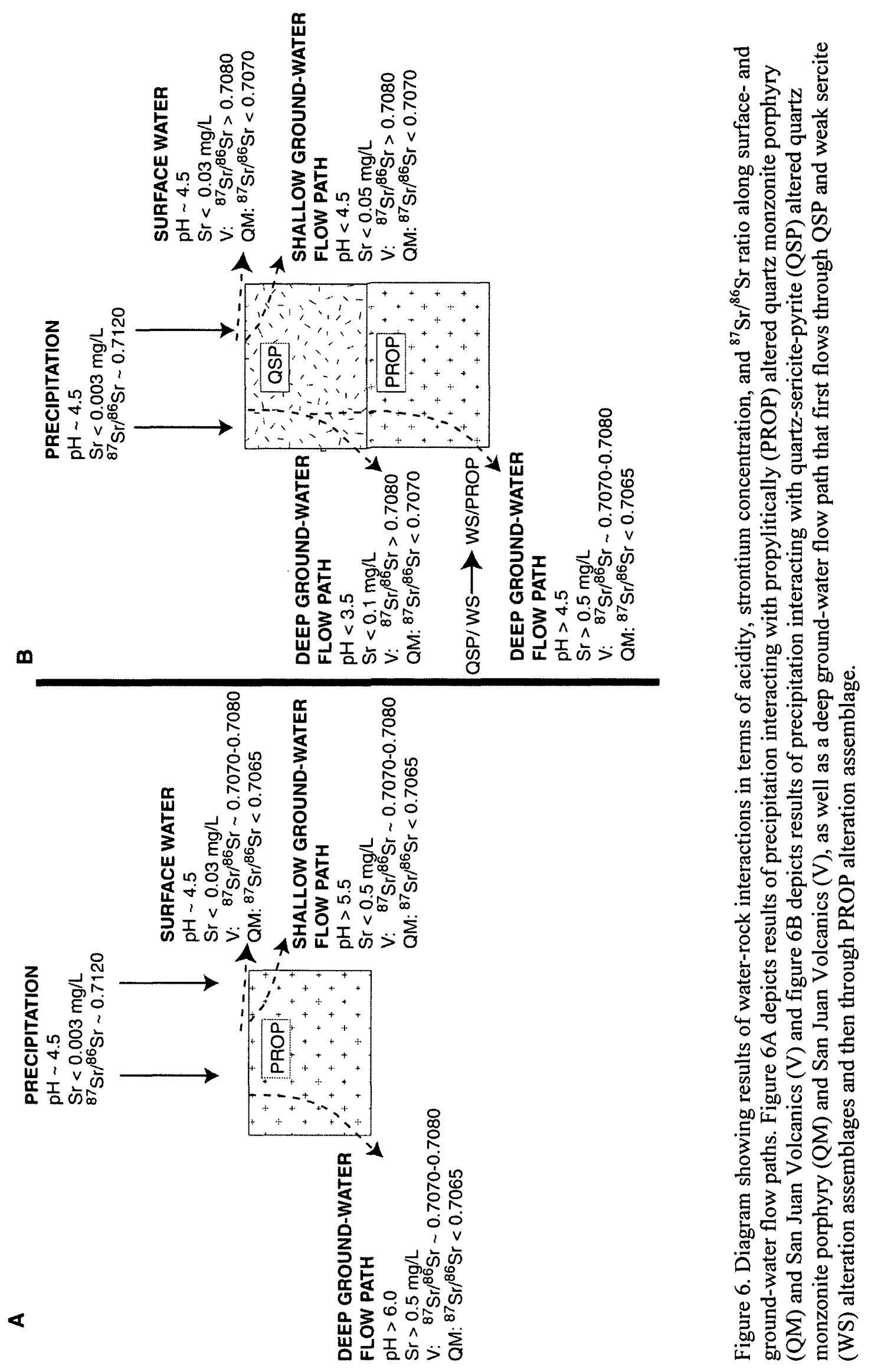


ratio are quite similar, demonstrating that in this environment the ${ }^{87} \mathrm{Sr} /{ }^{86} \mathrm{Sr}$ cannot be used as a tool for separating mining impacted waters from naturally acidic drainage.

Similarly, sample M5, adit effluent within weak sericitically altered San Juan Volcanics, has a pH of 5.7 and ${ }^{87} \mathrm{Sr} /{ }^{86} \mathrm{Sr}$ ratio of 0.70853 , which is within the range of nearby springs (pH of 5.7 to 6.8 and ${ }^{87} \mathrm{Sr} /{ }^{86} \mathrm{Sr}$ of 0.70808 to $0.70899 ; \mathrm{P} 7, \mathrm{P} 17$, and $\mathrm{P} 18$ ). Within the study area, the strontium isotopic ratios of the water samples are controlled by the bedrock and alteration assemblages. The mining activity focused on base-metal-rich quartz veins, which do not appear to have unique strontium isotopic compositions.

Figure 6B also illustrates the possible resulting acidity and strontium isotopic ratio of a water that has a flow path through QSP altered units and then through a propylitically altered unit. This flow path is quite likely, because the more intense alteration is centered at higher elevations on Mount Moly, and the less intense alteration occurs along the periphery. Water passing through the QSP altered units will become quite acidic ( $\mathrm{pH}$ less than 4) and will gain strontium with an isotopic ratio similar to the leach results from the more intensely altered rock samples. When flowing through the propylitic assemblage, this acidic water will react, and the $\mathrm{pH}$ will increase because of dissolution of calcium-rich minerals. The carbonate-rich minerals are generally high in strontium and have a lower isotopic composition than the minerals in the QSP altered material. The final ${ }^{87} \mathrm{Sr} /{ }^{86} \mathrm{Sr}$ of the water will likely shift towards propylitic alteration values.

\section{SUMMARY}

This study in the MFMC subbasin was a reconnaissance investigation focusing on the application of strontium isotopic systematics to constrain ground-water flow paths. Springs, streams, and adit drainages were sampled to determine the range of water compositions throughout the study area. Rock samples from the different lithologies and the same lithology with different alteration assemblages were collected, leached, and analyzed for both their whole-rock and leachate compositions. Comparison of the leachate results with the water samples provides insight into the range of strontium isotopic compositions expected from water-rock interactions. The following are the most significant conclusions based on these results:

1. Variations in whole-rock ${ }^{87} \mathrm{Sr} /{ }^{86} \mathrm{Sr}$ ratios correlate with lithology and alteration intensity; for a given alteration assemblage, the porphyritic quartz monzonite has a lower ${ }^{87} \mathrm{Sr} /{ }^{86} \mathrm{Sr}$ ratio than the San Juan Volcanics.

2. For a given lithology, the ${ }^{87} \mathrm{Sr} /{ }^{86} \mathrm{Sr}$ ratio is lower for propylitically altered samples than for quartzsericite-pyrite (QSP) altered samples because the ${ }^{87} \mathrm{Rb} /{ }^{86} \mathrm{Sr}$ is greater in the QSP altered samples.

3. Initial ${ }^{87} \mathrm{Sr} /{ }^{86} \mathrm{Sr}$ ratio, calculated at $25.1 \mathrm{Ma}$, for the porphyritic quartz monzonite $(0.70607$ and $0.70615)$ is lower than the initial ${ }^{87} \mathrm{Sr} /{ }^{86} \mathrm{Sr}$ ratio for the San Juan Volcanics $(0.70687$ and 0.70698$)$ which is consistent with the interpretation of Riciputi and others (1995) that the shift to less radiogenic values reflects hybridization of the upper and lower crust by mantle-derived melts.

4. The ${ }^{87} \mathrm{Sr} /{ }^{86} \mathrm{Sr}$ ratios of the 4-hour leachates are slightly higher than the whole-rock ${ }^{87} \mathrm{Sr} /{ }^{86} \mathrm{Sr}$ ratios. A rubidium-rich mineral phase, such as sericite or biotite, may be preferentially leached, or ${ }^{87} \mathrm{Sr}$ produced by radioactive decay of ${ }^{87} \mathrm{Rb}$ may be less well bound in mineral structures, such that it can be more easily leached than ${ }^{86} \mathrm{Sr}$ in the host minerals.

5. Waters draining different lithologies and alteration assemblages have different strontium isotopic ratios, but because the age of magmatism and alteration is relatively young compared to the halflife of ${ }^{87} \mathrm{Rb}$, the variation in ${ }^{87} \mathrm{Sr} /{ }^{86} \mathrm{Sr}$ ratios is not great enough to determine mixing ratios for waters derived from different sources. Furthermore, variables such as acidity, residence time, and heterogeneities in alteration zones influence the isotopic composition of the water.

6. In this study area, adit drainage does not have a unique strontium isotopic composition because the mineral deposits do not have an isotopic composition distinctly different from the host rocks. 


\section{REFERENCES CITED}

Aberg, Goran, Jacks, Gunnar, and Hamilton, P.J., 1989, Weathering rates and ${ }^{87} \mathrm{Sr} /{ }^{86} \mathrm{Sr}$ ratios: an isotopic approach: Journal of Hydrology, v. 109, p. 65-78.

Armstrong, R.L., 1968, A model for the evolution of strontium and lead isotopes in a dynamic earth: Reviews in Geophysics, v. 6, p. 75-199.

Bain, D.C. and Bacon, J.R., 1994, Strontium isotopes as indicators of mineral weathering in catchments: Catena, v. 22, p. 201-214.

Baumgartner, L.P. and Olsen, S.N., 1995, A least-square approach to mass transport calculations using the isocon method: Economic Geology, v. 90, p. 1261-1270.

Bigham, J.M. and Nordstrom, D.K., 2000, Iron and aluminum hydroxysulfates form acid sulfate waters, in Alpers, C.N., Jambor, J.L, and Nordstrom, D.K., eds. Sulfate minerals: crystallography, geochemistry and environmental significance: Washington, D.C., Mineralogical Society of America, Reviews in Mineralogy and Geochemistry, v. 40, p 351-403.

Bove, D.J., Hon, Kenneth, Budding, K.E., Slack, J.F., Snee, L.W., and Yeoman, R.A., 1999, Geochronology and geology of late Oligocene through Miocene volcanism and mineralization in the Western San Juan Mountains, Colorado: U.S. Geological Survey Open-File Report 99-347, 35 p.

Briggs, P.H., 1996, Forty elements by inductively coupled-plasma atomic emissionnspectrometry, in Arbogast, B.F. ed., Analytical methods manual for the mineral resources program: U.S. Geological Survey Open-File Report 96-525, p. 7-94.

Bullen, T.D., Krabbenhoft, D.P., and Kendall, Carol, 1996, Kinetic and mineralogic controls on the evolution of ground water chemistry and ${ }^{87} \mathrm{Sr} /{ }^{86} \mathrm{Sr}$ in a sandy silicate aquifer, northern Wisconsin, USA: Geochimica et Cosmochimica Acta, v. 60, p. 1807-1821.

Burbanke, W.S., 1960, Pre-ore propylitization, Silverton, caldera, in Short papers in the geologic sciences: U.S. Geological Survey Professional paper 400-B, p. B12-B13.

Church, S.E., Fey, D.L., Unruh, D.M., Vaughn, R.B., and Taggart, J.E. Jr., 2000, Geochemical and isotopic data from stream sediments, Animas River watershed, Colorado, 1995-1999: U.S. Geological Survey Open-File Report 2000-244, 14 p.

Clow, D.W., Mast, M.A., Bullen, T.D., and Turk, J.T., 1997, Strontium 87/strontium 86 as a tracer of mineral weathering reactions and calcium sources in an alpine watershed, Loch Vale, Colorado: Water Resource Research, v. 33, p. 1335-1351.

Faure, Gunter, 1986, Principles of isotope geology ( $2^{\text {nd }}$ ed.): New York, Wiley, 589 p.

Farmer, G.L. and DePaolo, D.J., 1987, Nd and Sr isotope study of hydrothermally altered granite at San Manuel, Arizona: implications for element migration paths during the formation of porphyry copper ore deposits: Economic Geology, v. 82, p. 1142-1151.

Farmer, G.L., Broxton, D.E., Warren, R.G., and Picthorn, William, 1991, Nd, Sr, and O isotopic variations in metaluminous ash-flow tuffs and related volcanic rocks at the Timber Mountain/Oasis Valley Caldera Complex, SW Nevada; implications for the origin and evolution of large-volume silicic magma bodies: Contributions to Mineralogy and Petrology, v. 109, p. 53-68.

Gopalan, K. and Wetherill, G.W., 1970, Rubidium-strontium studies on enstatite chondrites; whole meteorite and mineral isochrones: Journal of Geophysical Research, v. 75, p. 3457-3467.

Grant, J.A., 1986, The isocon diagram-a simple solution to Gresen's equation for metasomatic alteration: Economic Geology, v. 81, p. 1976-1982.

Hurley, P.M., Bateman, P.C., and Steven, T.A., 1965, Investigation of initial ${ }^{87} \mathrm{Sr} /{ }^{86} \mathrm{Sr}$ ratios in the Sierra Nevada plutonic province: Geological Society of America Bulletin, v. 76, p. 165-174.

Kendall, Carol, Sklash, M.G., and Bullen, T.D., 1995, Isotope tracers of water an solute sources in Catchments: in S.T. Trudgill, ed., Solute modelling in catchment systems, New York, Wiley, p. 261-303. 
Lipman, P.W., Fisher, F.S., Mehnert, H.H., Nasser, C.W., Luedke, R.G., and Steven, T.A, 1976, Multiple ages of mid-Tertiary mineralization and alteration in the western San Juan Mountains, Colorado: Economic Geology, v. 71, p. 571-588.

Lipman, P.W., Doe, B.R., Hedge, C.E., and Steven, T.A., 1978, Petrologic evolution of the San Juan volcanic field, southwestern Colorado: $\mathrm{Pb}$ and $\mathrm{Sr}$ isotope evidence: Geological Society of America Bulletin, v. 89, p. 59-82.

Lowell, J.D and Guilbert, J.M., 1970, Lateral and vertical alteration-mineralization in porphyry ore deposits: Economic Geology, v. 65, p. 373-408.

Luedke, R.G., 1996, Geologic map of the Ophir Quadrangle, San Juan, San Miguel, and Dolores counties, Colorado: U. S. Geological Survey: Geologic Quadrangle GQ-1760.

Mast, M.A., Verplanck, P.L., Yager, D.B., Wright, W.G., and Bove, D.J., 2000, Natural sources of metals of surface waters in the upper Animas River watershed, Colorado: in International Conference on Acid Rock Drainage, Denver, Colo.: Littleton, Colo., Society for Mining, Metallurgy, and Exploration, Inc., v. 2, p. 513-522.

McNutt, R.H., Frape, S.K., Fritz, Peter, Jones, M.G., and MacDonald, I.M., 1990, The ${ }^{87} \mathrm{Sr} /{ }^{86} \mathrm{Sr}$ values of Canadian Shield brines and fracture minerals with applications to ground water mixing, fracture history, and geochronology: Geochimica et Cosmochimica Acta, v. 54, p. 205-215.

Minster, F.L. and Allegre, C.J., 1976, ${ }^{87} \mathrm{Rb}-{ }^{87} \mathrm{Sr}$ history of the Norton County enstatite achondrite: Earth and Planetary Science Letters, v. 32, p. 191-198.

Moorbath, S., Allaart, J.H., Bridgewater, D., and McGregor, V.R., 1977, Rb-Sr ages of early Archaean supracrustal rocks and Amitsoq gneisses at Isua: Nature, v. 270, p. 43-44.

Ransome, F.L., 1901, A report on the economic geology of the Silverton quadrangle, Colorado: U.S. Geological Survey Bulletin 182, 265 p.

Riciputi, L.R., Johnson, C.M., Sawyer, D.A., and Lipman, P.W., 1995, Custal and magmatic evolution in a large multicycle caldera complex: isotopic evidence from the central San Juan volcanic field: Journal of Volcanolgy and Geothermal Research, v. 67, p. 1-28.

Ringrose, C.R., 1982, Geology, geochemistry, and stable isotope studies of a porphyry-style hydrothermal system, west Silverton district, San Juan Mountains, Colorado: Aberdeen, Scotland, University of Aberdeen, Ph. D. dissertation, $256 \mathrm{p}$.

Smith, K.S., Walton-Day, Katherine, and Ranville, J.F., 2000, Evaluating the effects of fluvial tailings deposits on water quality in the upper Arkansas River basin, Colorado: Observation scale considerations: in International Conference on Acid Rock Drainage, Denver, Colo.: Littleton, Colo., Society for Mining, Metallurgy, and Exploration, Inc., v. 2, p. 1415-1424.

Wadleigh, M.A., Veizer, Jan, and Brooks, Christopher, 1985, Strontium and its isotopes in Canadian rivers: fluxes and global implications: Geochimica et Cosmochimica Acta, v. 49, p. 1727-1736.

Yager, D.B., Mast, M.A., Verplanck, P.L., Bove, D.J., Wright, W.G., and Hageman, P.L. 2000, Natural versus mining-related water quality degradation to tributaries draining Mount Moly, Silverton, Colorado: in International Conference on Acid Rock Drainage, Denver, Colo.: Littleton, Colo., Society for Mining, Metallurgy, and Exploration, Inc., v. 2, p. 535-550. 
Appendix. Selected elemental concentrations of whole-rock samples

[Fm, formation; Qtz Monz., quartz monzonite; ppm, parts per million; <, less than]

\begin{tabular}{|c|c|c|c|c|c|c|c|}
\hline Sample & 8101 & 8102 & 8103 & 8104 & 8105 & 8106 & 8108 \\
\hline Rock Unit' & Burns Fm & $\begin{array}{l}\text { Sapinero } \\
\text { Mesa Tuff }\end{array}$ & $\begin{array}{l}\text { Sapinero } \\
\text { Mesa Tuff }\end{array}$ & San Juan Fm & San Juan Fm & San Juan Fm & $\begin{array}{l}\text { Qtz Monz. } \\
\text { Porphyry }\end{array}$ \\
\hline Alteration type & Propylitic & Propylitic & Propylitic & Propylitic & Propylitic & Propylitic & Propylitic \\
\hline Longitude & 1074515 & 1074519 & 1074525 & 1074529 & 1074606 & 1074556 & 1074350 \\
\hline Latitiude & 375104 & 375102 & 375102 & 375101 & 375059 & 375052 & 375001 \\
\hline \multicolumn{8}{|c|}{ Concentration, in weight percent } \\
\hline $\mathrm{Al}$ & 8.6 & 8.2 & 8.7 & 8.1 & 10 & 7.1 & 8.1 \\
\hline $\mathrm{Ca}$ & 2.7 & 2.8 & 3.3 & 0.80 & 4.0 & 0.30 & 0.94 \\
\hline $\mathrm{Fe}$ & 3.6 & 4.3 & 4.1 & 3.9 & 5.7 & 4.8 & 3.1 \\
\hline $\mathrm{K}$ & 2.9 & 2.6 & 1.2 & 3.2 & 2.0 & 1.6 & 3.4 \\
\hline $\mathrm{Mg}$ & 0.87 & 0.89 & 1.2 & 1.2 & 1.4 & 0.25 & 0.93 \\
\hline $\mathrm{Na}$ & 2.7 & 2.4 & 3.2 & 2.6 & 2.6 & 1.9 & 2.7 \\
\hline$P$ & 0.13 & 0.12 & 0.13 & 0.10 & 0.15 & 0.01 & 0.10 \\
\hline $\mathrm{Ti}$ & 0.35 & 0.37 & 0.22 & 0.35 & 0.37 & 0.26 & 0.14 \\
\hline \multicolumn{8}{|c|}{ Concentration, in parts per million } \\
\hline $\mathrm{Ag}$ & $<2$ & $<2$ & $<2$ & $<2$ & $<2$ & $<2$ & $<2$ \\
\hline As & $<10$ & 16 & 15 & 13 & $<10$ & $<10$ & $<10$ \\
\hline $\mathrm{Au}$ & $<8$ & $<8$ & $<8$ & $<8$ & $<8$ & $<8$ & $<8$ \\
\hline $\mathrm{Ba}^{2}$ & 1390 & 968 & 769 & 1220 & 1600 & 854 & 816 \\
\hline $\mathrm{Be}$ & 1 & 1 & 1 & 2 & 2 & 1 & 2 \\
\hline $\mathrm{Bi}$ & $<10$ & $<10$ & $<10$ & $<10$ & $<10$ & $<10$ & $<10$ \\
\hline $\mathrm{Cd}$ & $<2$ & $<2$ & 2 & $<2$ & 3 & $<2$ & $<2$ \\
\hline $\mathrm{Ce}$ & 80 & 77 & 73 & 92 & 96 & 72 & 97 \\
\hline Co & 13 & 13 & 12 & 11 & 15 & 12 & 11 \\
\hline $\mathrm{Cr}$ & 1 & 23 & $<1$ & 5 & $<1$ & 1 & $<1$ \\
\hline $\mathrm{Cu}$ & $<1$ & 7 & $<1$ & 11 & 5 & 15 & 99 \\
\hline $\mathrm{Eu}$ & $<2$ & $<2$ & $<2$ & $<2$ & 2 & $<2$ & $<2$ \\
\hline $\mathrm{Ga}$ & 16 & 12 & 12 & 16 & 19 & 11 & 15 \\
\hline Ho & $<4$ & $<4$ & $<4$ & $<4$ & $<4$ & $<4$ & $<4$ \\
\hline $\mathrm{La}$ & 44 & 41 & 39 & 50 & 50 & 39 & 52 \\
\hline $\mathrm{Li}$ & 22 & 18 & 15 & 12 & 13 & 35 & 17 \\
\hline $\mathrm{Mn}$ & 990 & 670 & 1700 & 970 & 1500 & 96 & 340 \\
\hline Mo & $<2$ & $<2$ & $<2$ & $<2$ & $<2$ & $<2$ & $<2$ \\
\hline $\mathrm{Nb}$ & 21 & 19 & 14 & 23 & 25 & 16 & 14 \\
\hline $\mathrm{Nd}$ & 35 & 34 & 32 & 40 & 46 & 32 & 42 \\
\hline $\mathrm{Ni}$ & 7 & 10 & 7 & 11 & 7 & 8 & 8 \\
\hline $\mathrm{Pb}$ & 16 & 22 & 29 & 32 & 20 & 24 & 52 \\
\hline $\mathrm{Sc}$ & 11 & 11 & 13 & 12 & 10 & 12 & 8 \\
\hline $\mathrm{Sn}$ & $<5$ & $<5$ & $<5$ & $<5$ & $<5$ & $<5$ & $<5$ \\
\hline $\mathrm{Sr}$ & 740 & 640 & 420 & 540 & 710 & 330 & 460 \\
\hline $\mathrm{Ta}$ & $<40$ & $<40$ & $<40$ & $<40$ & $<40$ & $<40$ & $<40$ \\
\hline Th & 5 & $<4$ & $<4$ & 20 & $<4$ & $<4$ & 29 \\
\hline $\mathrm{U}$ & $<100$ & $<100$ & $<100$ & $<100$ & $<100$ & $<100$ & $<100$ \\
\hline V & 80 & 75 & 78 & 110 & 72 & 78 & 72 \\
\hline $\mathrm{Y}$ & 19 & 19 & 17 & 18 & 21 & 4 & 25 \\
\hline $\mathrm{Yb}$ & 2 & 2 & 2 & 2 & 2 & $<1$ & 2 \\
\hline $\mathrm{Zn}$ & 110 & 92 & 150 & 130 & 130 & 23 & 46 \\
\hline $\mathrm{Rb}^{2}$ & 84 & 80 & 43 & 97 & 65 & 92 & 130 \\
\hline $\mathrm{Sr}^{2}$ & 728 & 650 & 410 & 549 & 665 & 366 & 468 \\
\hline
\end{tabular}

'Unit designation as mapped by Ringrose (1982) and Luedke (1996).

${ }^{2}$ Element determined by energy-dispersive X-ray fluorescence. 
Appendix. Selected elemental concentrations of whole-rock samples - continued

[Fm, formation; Qtz Monz., quartz monzonite; ppm, parts per million; <, less than]

\begin{tabular}{|c|c|c|c|c|}
\hline Sample & 9801B & 9802 & 9706 & 9713 \\
\hline Rock Unit ${ }^{\prime}$ & San Juan FM & San Juan FM & $\begin{array}{l}\text { Qtz Monz. } \\
\text { Porphyry }\end{array}$ & $\begin{array}{l}\text { Qtz Monz. } \\
\text { Porphyry }\end{array}$ \\
\hline Alteration type & Propylitic & Prop/WS & QSP & QSP \\
\hline Longitude & 1074547 & 1074523 & 1074358 & 1074436 \\
\hline \multirow[t]{2}{*}{ Latitiude } & 374932 & 375004 & 374959 & 374957 \\
\hline & \multicolumn{4}{|c|}{ Concentration, in weight percent } \\
\hline $\mathrm{Al}$ & 8.8 & 8.3 & 7.5 & 7.6 \\
\hline $\mathrm{Ca}$ & 5.8 & 2.6 & 0.20 & 0.10 \\
\hline $\mathrm{Fe}$ & 7.7 & 5.1 & 2.6 & 0.45 \\
\hline $\mathrm{K}$ & 2.2 & 1.2 & 3.4 & 3.5 \\
\hline $\mathrm{Mg}$ & 2.4 & 1.3 & 0.55 & 0.48 \\
\hline $\mathrm{Na}$ & 1.8 & 2.9 & 2.4 & 0.14 \\
\hline $\mathbf{P}$ & 0.24 & 0.15 & 0.08 & 0.10 \\
\hline \multirow[t]{2}{*}{$\mathrm{Ti}$} & 0.78 & 0.46 & 0.14 & 0.14 \\
\hline & \multicolumn{4}{|c|}{ Concentration, in parts per million } \\
\hline Ag & $<2$ & $<2$ & $<2$ & $<2$ \\
\hline As & 18 & 12 & 14 & $<10$ \\
\hline $\mathrm{Au}$ & $<8$ & $<8$ & $<8$ & $<8$ \\
\hline $\mathrm{Ba}^{2}$ & 890 & 554 & 758 & 1520 \\
\hline $\mathrm{Be}$ & 1 & 1 & 2 & $<1$ \\
\hline $\mathrm{Bi}$ & $<10$ & $<10$ & $<10$ & $<10$ \\
\hline $\mathrm{Cd}$ & 4 & 2 & $<2$ & $<2$ \\
\hline $\mathrm{Ce}$ & 98 & 74 & 68 & 38 \\
\hline Co & 27 & 14 & 8 & 4 \\
\hline $\mathrm{Cr}$ & 39 & 11 & $<1$ & 3 \\
\hline $\mathrm{Cu}$ & 85 & 260 & 30 & 28 \\
\hline $\mathrm{Eu}$ & 2 & $<2$ & $<2$ & $<2$ \\
\hline $\mathrm{Ga}$ & 15 & 18 & 14 & 18 \\
\hline Ho & $<4$ & $<4$ & $<4$ & $<4$ \\
\hline $\mathrm{La}$ & 51 & 39 & 37 & 22 \\
\hline $\mathrm{Li}$ & 20 & 17 & 12 & 4 \\
\hline $\mathrm{Mn}$ & 1200 & 1000 & 110 & 34 \\
\hline Mo & $<2$ & $<2$ & 8 & 9 \\
\hline $\mathrm{Nb}$ & 19 & 17 & 15 & 19 \\
\hline $\mathrm{Nd}$ & 47 & 35 & 27 & 13 \\
\hline $\mathrm{Ni}$ & 19 & 11 & 6 & $<2$ \\
\hline $\mathrm{Pb}$ & 17 & 33 & 34 & 29 \\
\hline $\mathrm{Sc}$ & 28 & 15 & 8 & 13 \\
\hline $\mathrm{Sn}$ & $<5$ & $<5$ & $<5$ & 8 \\
\hline $\mathrm{Sr}$ & 760 & 600 & 420 & 200 \\
\hline $\mathrm{Ta}$ & $<40$ & $<40$ & $<40$ & $<40$ \\
\hline Th & $<4$ & $<4$ & 31 & 14 \\
\hline $\mathrm{U}$ & $<100$ & $<100$ & $<100$ & $<100$ \\
\hline $\mathrm{V}$ & 230 & 120 & 64 & 110 \\
\hline $\mathrm{Y}$ & 28 & 22 & 8 & 2 \\
\hline $\mathrm{Yb}$ & 3 & 3 & $<1$ & $<1$ \\
\hline $\mathrm{Zn}$ & 120 & 90 & 25 & 8 \\
\hline $\mathrm{Rb}^{2}$ & 47 & 60 & 141 & 157 \\
\hline $\mathrm{Sr}^{2}$ & 687 & 595 & 456 & 243 \\
\hline
\end{tabular}

${ }^{\top}$ Unit designation as mapped by Ringrose (1982) and Luedke (1996).

${ }^{2}$ Element determined by energy-dispersive X-ray fluorescence. 